日本臨床麻酔学会第 38 回大会シンポジウム 日臨麻会誌 Vol.40 No.2, $186 \sim 189,2020$

\title{
女性麻醉科医の役割一働き方改革の時代をすべての麻醉科医が輝くために イクボスからみた女性麻酔科医の役割
}

上村裕一*

\begin{abstract}
[要旨］女性医師の比率が高い麻酔科では，女性医師が麻酔科医として勤務できる体制を整備する ことが，マンパワー充実のために必須であり，女性麻酔科医が勤務を続けるための支援を行うのは 上司の義務である. 現在部下の育児参加に理解のあるイクボスであることが上司に求められるよう になっているが, 職場としての環境整備に関して病院が理解をもつことも求められている. また女 性医師自身の環境も大きく異なっている．したがって，画一的な原則を作るのではなく状況に応じ た柔軟な対応を行うことが，女性医師支援に重要である.

キーワード : イクボス, 女性麻酔科医
\end{abstract}

\section{はじめに}

現在医師国家試験に合格して初期臨床研修を開始 する医師の $1 / 3$ が女性であり, 研修終了後麻酔科を 選択する専攻医の過半数が女性である。他科よりも 女性医師の比率が高い麻酔科では, 女性医師が麻酔 科医として勤務できる体制を整備することが，マン パワー充実のために必須であり，ひいては日本の周 術期医療を支えるための要件である.

そのためには, 女性医師が勤務を続けるための支 援を行うのが上司の義務であるが，その上司は女性 が増えつつあるがまだ多くは男性であり，彼らが女 性医師の支援に積極的に関わる＝イクボスとなるこ とが, 求められている。

\section{I イクボスとは}

イクボスとは，部下の育児参加に理解がある経営 者や上司のことであり, 子育てに積極的に関わる男
性のことをイクメンと呼ぶのに基づき名付けられ た.イクメンを職場で支援する上司のことであるが, それだけでなく部下の育児休業取得を促すなど，仕 事と育児を両立しやすい環境の整備に努める上司の ことでもある．当然組織のリーダーであるので，組 織の業績において結果を出すことが求められるとと もに，部下の個々の状況を考慮し彼らのキャリアと 人生を応援することが求められる。

イクボスに求められる条件として以下の項目があ げられる ${ }^{1)}$.

1) 理解 : 部下が，子育て・介護等に時間を割くこと に理解を示す。

2)多様性：仕事以外に時間を割いている部下を差別 せず，多様性を尊重する。

3) 知識：関連する社内制度 (育休制度など) や法律 (労基法など)を知っている.

4)組織浸透：管轄する組織全体に，子育て・介護等 に積極的に時間を割くことを推奨する。 
5) 配慮：転勤や単身赴任など，部下の生活に大きく 影響を及ぼす人事については, 最大限の配慮を行 う。

6) 業務：育休取得者が出ても業務に支障が出ないよ うに，情報共有やチームワークなどの手段を講ず る。

7)時間捻出：部下が時間を取りやすいように，会議 や書類の削減，意思決定の迅速化などを進める。

8)経営目線：ボスの上司や人事部などに対し, 社員 の子育て・介護等を重視した経営をするよう, 提 言する。

9)自らのワーク・ライフ・バランス : 自身が仕事・ 私生活・社会貢献等の, ワーク・ライフ・バラン スを重視し，生活を楽しんでいる。

10)業績達成: 組織の責任者として, その職責を全 うし，業績をあげる。

\section{II 女性医師の勤務継続を阻害する要因}

現状では，女性医師が勤務を継続するために理解 のある上記のようなイクボスは非常に少ない。また イクボスの存在以前に, わが国で女性医師の継続的 社会参加を阻害する因子が多く存在する。以下にあ げるこれらの因子を理解して女性医師の勤務が継続 できるような体制を構築する必要がある。

1) 医師の過酷な労働環境

2) 日本社会の社会的性差への認識不足 (男性優位の 社会文化)

3) 日本社会の多様性を受け入れる意識の欠如

4) 医師としての社会的使命感の欠如

さらにこれらの因子の結果として，以下のような 問題点があげられる。

1)育児支援システム (保育所等)の不備

2)多彩なロールモデルの不在

3) 柔軟な人生設計能力の欠如

その他の問題点もあると思われるが，これらの課 題を解決しなければ，女性医師の勤務継続は難しい ままになる。

\section{III 当教室での対策}

他大学と同様に，当教室でも医局員に占める女性 の割合は増加の一途である。当然産休・育休から復 帰する女性医師も多くなっていた。その際に勤務に 復帰するための相談を受けることがあったが，今か ら思えばまったく役に立たないアドバイスが多かっ たと思う。

そのため, 女性医師が相談するのは育児経験のあ る女性医師でなければならないと考えたが，当時大 学内にはそのような女性医師がいなかったので，民 間病院に勤務し 3 児を育児中であった女性医師にお 願いし，女性医師の相談役として大学の講師に復帰 してもらった。彼女は後に病院の女性医師等支援セ ンター副センター長に就任するが，彼女が中心とな つて女性医師全員が専門医を取得できる環境整備と カリキュラム作成に努め, 現在は専門医取得後も専 門医の維持ができる体制を整備している.

しかし，環境整備に関してすべての病院が全面的 に協力してくれる状況ではなく，また麻酔科部長の 対応にもばらつきが大きく，そして女性医師自身の 環境も大きく異なっている。したがって，画一的な 原則を作るのではなく状況に応じた柔軟な対応を行 うことが，女性医師支援の重要な点と考えられる。 これまでの当教室の女性医師支援の経緯と現状につ いて以下に述べる。

\section{1. 保育所設置の要請}

女性医師だけでなく育児中の女性の勤務を妨げて いるのが保育所不足であることは，大きな社会的問 題となっている。当教室でも女性医師の復帰の際の 保育所の確保が，女性医師等支援センター副センタ 一長の最も重要な仕事である. 院内保育所の設置は, 民間病院では進んできているが，公的病院では対応 が遅く，当大学病院でも 10 年前に設置された。し かしいまだ設置されていない施設も多く，そのよう な施設には将来麻酔科医だけでなく他科の女性医師 の勤務も困難になる可能性があることを伝え，早急 
の対応を要請している.

\section{2. 女性医師が復帰できる勤務体制}

以前の大学病院の医員の勤務体制は，1日8時間， 週 4 日勤務が原則であったが，その条件では育児中 の女性医師はほとんどが勤務できなかった。そのた め病院にお願いし，2007年に「医員の多様な働き 方に関する規定」を制定していただいた。この制度 は， 1 日 8 時間・ 6 時間・ 4 時間勤務の中から働ける 時間を選択し，週 $1 \cdot 2 \cdot 3$ 日から勤務する日数を選 択するものである。この制度の優れている点は, 講 座配分定数を超えた場合，この制度により勤務する 医員については病院予算で対処できるようにしてい る点である。この制度以前は各講座で医員配分定数 が決められているため，フルタイムで勤務可能な医 師が優先的に雇用され，フルタイム勤務や時間外勤 務ができない育児中の医師は無給で研究生として診 療に従事するか, パート勤務の可能な関連病院へ出 向するかといった選択を迫られることが多い状況で あった。そのため, 育児休業後復帰することなく退 職する医師が後を絶たなかった。しかしこの規定制 定後，フルタイムで働く医員数を減らすことなく短 時間勤務医師の雇用が可能となり，女性医師の復帰 が進んでいる。

\section{3. 病院全体としての女性医師支援体制}

大学全体として女性職員・研究者を支援するため の男女共同参画推進センターがあり, 女性研究者へ の研修活動支援事業も行われているが，附属病院に は女性医師等支援センターが設置され, 女性医師だ けでなく看護師・薬剤師・臨床工学技士等のすべて の女性職員の復職支援, キャリアアップ支援を行っ
ている.

現在女性医師が最も多い麻酔科が中心となって活 動を行っており，麻酔科科長である著者がセンター 長を務め，前述した当科の講師であった女性医師が 副センター長として実務を行っている.

復職を考えている女性医師へのアドバイスを行う だけでなく，女子医学生や女性研修医に将来のため の情報提供を行う場を設け, 意見交換を行っている. また，各種支援(行政による公的支援，大学として の支援等)の情報提供も行っている.

\section{おわりに}

女性麻酔科医が勤務を続けるための支援を行うの は上司の義務だと考えるが，以前は上司(麻酔科部 長，麻酔科教授) はほとんどが男性であり，育児経 験はほとんどなく(現在の男性麻酔科医はそうでは ないと思うが), 女性医師が抱える問題の理解能力 に乏しかった。現在上司がイクボスであることが求 められるようになっているが，職場としての環境整 備に関してすべての病院が全面的に協力してくれる 状況ではない．また女性医師自身の環境も大きく異 なっている。したがって，画一的な原則を作るので はなく状況に応じた柔軟な対応を行うことが，女性 医師支援の重要な点と考えられる。

\section{参考文献}

1）イクボス 10 ケ条. ファザーリング・ジャパンホームペ ージ〈http://fathering.jp/ikuboss/about/10article/〉 (2019.3.26 閲覧) 


\title{
The Importance of Female Anesthesiologists in Relation to Ikuboss, or Bosses Who Comprehend Childcare
}

\author{
Yuichi KANMURA \\ Department of Anesthesiology, Kagoshima University Hospital
}

One-third of graduates of medical school are now female, and more than half of new anesthesiologists are female. Therefore, employment support systems for female anesthesiologists are essential to ensure the manpower for perioperative medicine in Japan. To support female anesthesiologists, the role of their bosses is important. Ikuboss, which means bosses who comprehend childcare, are needed in departments of anesthesiology. To support the employment of female anesthesiologists, a department that supports female employees in the hospital is also important.

Key Words : Ikuboss, Female anesthesiologists

The Journal of Japan Society for Clinical Anesthesia Vol.40 No.2, 2020 